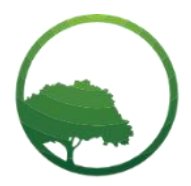

Research in Business \& Social Science

IJRBS VOL 10 NO 8 ISSN: 2147-4478

\title{
Female academics' views on work-life conflict in a Covid-19 global pandemic in Nigeria
}

\author{
Damson Adeoluwa Adewumi ${ }^{(a) *}$ (D) Princess Thulile Duma ${ }^{(b)}$ \\ ${ }^{(a, b)}$ Ph.D.Mangosuthu University of Technology, Human Resource Management Disciplin, Umlazi, South Africa
}

Crossref

\author{
A R T ICLE IN F O \\ Article history: \\ Received 02 December 2021 \\ Received in rev. form 21 Dec. 2021 \\ Accepted 22 December 2021 \\ Keywords: \\ Work, Covid-19, academic, women, \\ university, education \\ JEL Classification: \\ H75, J71, J82
}

\begin{abstract}
A B S T R A C T
Remarking on the importance of managing the existential conflict between work and family responsibilities, emphasis on female academics in a COVID-19 era in Nigeria has received diminutive research attention. The study seeks to address this research gap by interrogating women's views of work-life conflict narrative in a COVID-19 era. The exploratory research design was employed to expand the limit of the research gap and a total of 19 female academics were y recruited for interviews. The NVivo (v.12) qualitative software was employed to identify themes from the data and content analysis used to make sense of the various themes. The paper shows evidence of cultural bias in the recruitment and placement of female academics with social constraints hindering female academic capacity development. The long hours of teaching and consultation depict an indicator of work-life conflict with consequences on family support and emotional care for family and dependents. The need to acquire higher education qualifications on the part of females is also established as a pointer for the provocation of work-life conflict during the COVID-19 pandemic. The significance of lockdown constitutes major constraints for parenting mothers in the areas of combining home front responsibilities with work activities such as teaching, supervision, and the requirement of building a competitive career and research portfolio. The study concludes for a more robust measure in ensuring practical and realistic work-life conflict management strategies are introduced by managers of the University in order to aid the conflict between work and family responsibilities for female academics.
\end{abstract}

(C) 2021 by the authors. Licensee SSBFNET, Istanbul, Turkey. This article is an open access article distributed under the terms and conditions of the Creative Commons Attribution (CC BY) license (http://creativecommons.org/licenses/by/4.0/).

\section{Introduction}

The global purpose of work is the need for the promotion of a sustainable and healthy work pattern for all working class. However, the continuous rise of work-life conflict has conveyed a negative outlook on the sustainability of work engendering a spontaneous increase in the amount of conflict between the management of work and family responsibilities (Adisa, Adekoya \& Okoya, 2021). The occurrence of conflict between work and family responsibilities often leads to an undesirable repercussion for the individual including heightened risk in health and well-being, a declining participation towards family care and attachment and a decrease in life's commitment and relationships among other concerns (Agha, Azmi \& Irfa, 2017). The continuous changes in the workplace and demography of employees' have necessitate the study of the nexus of work and family conflict more important now than in the past. There has been an increase in the collection of studies in the areas of work-life conflict in the last two decades that has transmuted into the development of models, theories and practical organizational work-life conflict management initiatives (Boncori, 2020; Apodiari \& Lasisi, 2016).

Notwithstanding the increasing call for organisations, families and the individual employee to come to terms with the importance of ensuring a balance between the demands of work and family responsibilities, many women are still gripped with appropriating

* Corresponding author. ORCID ID: 0000-0003-4156-0971

(C) 2021 by the authors. Hosting by SSBFNET. Peer review under responsibility of Center for Strategic Studies in Business and Finance.

https://doi.org/10.20525/ijrbs.v10i8.1526 
balance between these two crucial facets of human life (Dumas \& Jeffrey, 2015). Research has been able to establish that contemporary women from all spheres of life desire to have it all including giving appropriate emotional care to the family and a glowing career. However, evidence abound that working woman encounter greater challenges than men in the management of worklife conflict (Lewis, 2016). This position supports the social and cultural constraints on women and the obligations as the principal custodian of the children, the elderly and the aged (especially in Africa) and the responsibilities attached to other domestic duties among others.

Studies have shown that a large constituent of working women found the balance work and family responsibilities extremely difficult in this COVID-19 era, particularly during the lockdown as a result of domestic and workload, lack of support from spouse and other stress variables (Manzo \& Minello, 2020; Qian \& Fuller, 2020). The literature shows that women academics roles and responsibilities at work and family have had to be doubled during the lockdown as a result of the introduction of the concept of work from home and the initiation of online teachings among others (Phillips, 2020). The remarkable increase in number of women affected by the global health pandemic with evidence of challenges between work and family, especially women in the specialized profession such as the academics calls for serious concern. For instance, the majority of women academics are severely affected in the areas of integrating academic tasks of supervision, consultation, teachings and research with other family responsibilities. In addition, COVID-19 and its associated challenges has limited the human capacity and academic development of many women academic parents with consequence on their research portfolio and the level of emotional and support care for families and relatives.

Given that the primary roles of academics are laced with the responsibilities of teaching and research, the present work place arrangements in line with the non-pharmaceutical prevention of the COVID-19 virus have leave many women academics with rousing health and psychological challenges rising from increase corporate and domestic workload (Qian \& Fuller, 2020). The concern of the cultural and social prejudiced against women has further compound the management of the conflict between work and family for women academics (Ugwu, 2017). The study focuses on the University of Lagos, Nigeria. The University relishes the presence of a metropolitan presence of Lagos with an approximate 55,000 students' population (National Universities Commission-NUC, 2018). Female academics are daily confronted with a number of academic responsibilities for these increasing population of students. This choice is justified to unravel female academics perception of work-life conflict in the COVID-19 global pandemic era. The literature is awash with discussions on work-life conflict with sparsity of studies on the implication of COVID-19 pandemic on the management of work and family responsibilities. In Nigeria, available studies include work-family conflict and family-work conflict as correlates of job performance (Ajala, 2017); institutional and organizational work-life balance policies and practices (Nwagbara, 2019); modern-day slavery? the work-life conflict of domestic workers in Nigeria (Adisa et al., 2021) and work-family role conflict and job performance among women banker (Apondiari \& Lasisi, 2016). Others include work-family role conflict and organizational commitment among industrial workers in Nigeria and relationship of work-family conflict, family work conflict and psychological distress (Aladejebi, 2019; Ugwu, 2017). In the canon of women studies in Nigeria, available studies including work life balance and role conflict of career women in Ekiti State (Agboola, 2019) and family and work responsibilities coping strategies (Fatoki \& Kobiowu, 2015). An interrogation of these array of studies depicts a research gap in the area of the impact of COVID-19 global health pandemic on women academic's views of work-life conflict.

The novelty of this paper is the interrogation of female academics' perception of work-life conflict in a COVID-19 pandemic era. By probing this important discourse, the study hopes to provoke a more nuance understanding of female academics' work-life conflict through the lens of the current global health pandemic. This analysis takes the fulcrum that managing work-life conflict is essentially relevant for the well-being of women academics in order to engender a striking balance between corporate and workloads. After the conceptualization and empirical discourse of work-life conflict, the paper shifts to unpack issues promoting work-life conflict. Thereafter, the Role Conflict Theory was reviewed as the theoretical frame of analysis. The different methodological approaches were expounded to address the questions raised in the paper. In specific, the qualitative research approach with the semi-structure interview type were employed to elicit data from a total of 19 female academics. The NVivo (v.12) qualitative software were further employed to make sense of the data with the emergence of different themes and sub-themes. The study echoes for a proactive approach on the part of the managers of higher institutions of learning in ensuring workable work-life conflict management strategies are constituted for reduced work-life conflict among female academics.

\section{Literature Review}

\section{Theoretical and Conceptual Background}

The conceptualization of work-life conflict captures how people manage their time through a range of determinant variables including priorities, personality and environment (Agha et al., 2017). According to Lewis (2016) work-life conflict is determined by how time and work allocation can be appraised in order to provoke a striking balance between work and family responsibilities. Theoretically, it extends to the conversation on time management for working individuals who combine family and work responsibilities. The narrative of allocating time for work and family responsibilities may seem to have been taken for granted by many professional mothers, the fallout ensues with diverse problems such as the challenge in determining the quantity and quality of work and family responsibilities required to accomplish a balance between work and other non-work activities. Thus, the dual concept of work-life conflict seems to be at a cross-road that often lead to undesirable health conditions including depression, stress and anxiety among others (Helvaci, Bakalim \& Can, 2017; Pandu, Balu \& Poorani, 2013). 
Proponents of work-life conflict argue that work and family activities should meet at an equilibrium (Boncori, 2020; Agha et al., 2017). The overlapping roles, which are the consequence of long working hours and increase in domestic workload, have remain a challenge to the functional role of the majority of women (Adisa et al., 2021). Whilst women in contemporary societies have shifted from their traditional position of housewives, the original responsibilities of being a caregiver has seem not changed (Lewis, 2016). The academic sector has always been seen as a flexible work setting with male dominated. With the increasing number of women entrant in this sector, the traditional flexibility might need to be reconsidered. For instance, the massification of the education sector and reduction in funding have negatively affected academics world-wide. To be sure, the general increase in demand to possess higher qualifications $(\mathrm{PhD})$, improve research outputs, and contribution to community engagement have further escalate women's work-life conflicts on many grounds (Pandu et al., 2013).

The emergence of the COVID-19 global health pandemic has transformed and change the workings of many organisations (Boncori, 2020). The configuration of most work settings wherein employees spend most of their time at work whilst trying to sort other family responsibilities after work is now being reversed with remote working (Pandu et al., 2013). The new responsibility of homeschooling effect on mothers has extended their unpaid jobs to more than 4.4 hours per day as compared to men's unpaid job of 1.5 per day globally (Qian \& Fuller, 2020). The argument advance in this paper is the verity that COVID-19 has indeed disrupted the organisation of work leaving many working mothers on the negative side with an increase in conflict between work and family responsibilities (Boncori, 2020). In most Africa countries, taking care of family and house cores is predominantly conceived as women's obligation, regardless of their working status (Helvaci et al., 2017). This belief is associated with existing religious norms, patriarchal principles, social ethics and stigmatization. The instinct of motherhood forces females to take on more responsibilities of the 'unpaid shift' willingly. This has proven to engender a negative connotation and conflict in terms of work-life discourse (Agha et al., 2017).

\section{Empirical Review}

\section{Unpacking Issues Engendering Work-Life Conflicts Situations}

Role expectations and conflict does not exist in a void. Often times, external factors including socio-economic and other cultural constraint affect workers struggle in striking a balance between work and family responsibilities (Qian \& Fuller, 2020). Evaluating behavioural patterns showed by people in relation to their social realities, researchers tend to underrate the influence of external realities and exaggerate the influence of individualistic factors (Erickson, Giuseppe \& Jeffrey, 2010). For instance, in a number of developing societies, where national value stresses patriarchal orientations (i.e male ascendancy), this is likely to follow with gender stereotypes with a negative influence of women in employment. Such patriarchal society downgrade women and present them as a permanent home keeper with family responsibilities (Qian \& Fuller, 2020). It is expected that role conflict and the pressures between roles are agonizing realities for mothers in these cultures. The increasing rates of women with family responsibilities participation in labour markets across national setting have mostly been the basis for inter role conflict deliberations (Phillips, 2020). A number of the stress-related effects including depression, drinking, drug addiction and other occupational-related fallouts including absenteeism, health issues and turnover are examples of the harmful influence of work-life conflict (O'Connor \& Erin, 2018).

The emergence of the COVID-19 pandemic has sprout up work-life conflict issues for academics around the globe (Qian \& Fuller, 2020). COVID-19 has mandated many people to stay at home and reschedule their lives (Phillips, 2020). This narrative demonstrates the increase role obligation for women (Erickson et al., 2010). Children and other dependents are known with emotional attachment and care from their mothers and this has continued to oblige women into splitting their times and responsibilities (O'Connor \& Erin, 2018). Women tend to experience more stress and challenges of work-life conflict. This of course, may have arisen as result of the increase time and stress that comes with multitasking for women. Studies have been conducted on work-life conflicts, with sparsity of research on work-life conflict during COVID-19 health pandemic (Qian \& Fuller, 2020; O'Connor \& Erin, 2018; Dumas \& Jeffrey, 2015). For instance, an array of these studies have only provide technique and strategies for the management of work-life conflict leaving a void in the work-life conflict literature. This conclusion can be neatly laced through the analysis of Nigeria work environment where literature on women academic work-life conflict issues in a COVID-19 era is hardly explored. Thus, this study hopes to address this research gap.

\section{Theoretical Framework: The Role Conflict Theory}

The paper proceeds from the theoretical hypothesis of the Role Conflict Theory (RCT). On its origin, Katz and Kahn (1978) operationalized the RCT as the creation of systems and roles and the establishment of expectations for the fulfilment of these roles (Katz \& Kahn, 1978). The categorization of these roles can be explained through two different outlooks; the role sender (i.e the source of expectations) and the individual performing the role (i.e the individual functioning in the capacity of the role). One critical assumption of the theory is that the more perceived the expectations by the performer, the more likely conflict is to be provoked (Mentz, Schoeman \& Loock, 2019). Role conflict arises when existing status quo becomes unacceptable to an individual. The literature has identified fallouts from the violation of this status-quo including a feeling of distress, reduced confidence, respect and likeness for those events causing conflicts, emotional and social withdrawal (Örtqvist \& Wincent, 2006).

RCT is positioned as the foundation of most conflict arising between family and work responsibilities (Schulz, 2013). It is conceptualized as the concurrent occurrence of two or more collections of pressures in a way that submission to one would make compliance difficult to the other (George \& Zhou, 2002). The bottom-line assumption of the RCT is premised on the connection and 
the interface between and among roles, with the supposed severity of conflict when roles are considered significant to the individual and the obvious competing demands to comply with such pressure (Taggar, 2002). A more important component of the RCT is the consideration of outward observations of role expectations (George \& Zhou, 2002). How others reflect on the significance of roles such as organizational or family responsibilities also affect individual's perception of conflict. The theoretical application of the RCT to the understanding of conflicts between work and family responsibilities has continued to attract continued research attention (Onyemah, 2008). Although, it is safe to argue that work and family conflict remain a topical issue within the arena of management and family studies, the concerns provoked by the emergence of the COVID-19 has further escalate these arrays of conflict. With the current ravaging fallouts of the COVID-19 global health pandemic, accompanied with several work changes including the workfrom home policies adopted by many organisations, many work-life conflicts have continued to be evident among working mothers (Grunberg \& Matei, 2020). For instance, working from home has birth a new work paradigm and escalated family responsibilities for many working mothers, thus increasing work-life conflict indices.

The task of child and home caring on the one hand and work effectiveness on the other hand remain a source of conflict for female academic mothers. RCT discourse explains the existence of conflict between the drive and expectations to fulfilling work and family responsibilities. The paper argument can be laced through the understanding that work-life conflict depicts a discord between availing adequate responsibilities and roles for family care and work performance. This contention is supported with the increasing demands and stress associated with the need to work from home and the responsibilities of attending to other family demands and roles. The contention raised in this paper is the position that the expectations and demands from work and family responsibilities has continued to form the bedrock of conflict among working mothers.

\section{Research \& Methodology}

\section{Research Philosophy, Design and Population}

The conceptual understanding of the interpretivist approach supports the integration of human elements into a study. In other words, it seeks to qualitatively understand the meanings that humans convey into a research situation and the interpretations of these meanings (Creswell \& Plano-Clark, 2011). This assumption is employed to unravel the human elements of female academics' perception of work-life conflict in a COVID-19 global pandemic era. With the scarcity of academic literature on female academics' work-life conflict in a COVID-19 era in Nigeria, the exploratory research design is utilized to progress the limit of this research chasm. This is achieved through the exploration of answers through the qualitative-interview approach in order to appositely address the research problem. The population of study comprised a total of 19 female academics selected from the faculties of Education, Social Sciences and Arts/Humanities of the University of Lagos, Nigeria (see Table 1 for sample distribution). The selection of female academics takes into consideration specific features including job position, single females' academics and females' academics with dependents responsibilities, especially children. This sample clearly validates the principle of the qualitative methods where small size is employed to deeply unearth and understand a research problem (Sekaran \& Bougie, 2016).

Table 1: Demographic matrix of the sample by position and family responsibility

\begin{tabular}{llllll}
\hline Faculties & Junior Lecturer & Senior Lecturer & Married & Married with Children & Total \\
\hline Education & 2 & 2 & 1 & 2 & 7 \\
\hline Social Sciences & 1 & 2 & - & 3 & 6 \\
\hline Arts/Humanities & 2 & 1 & 1 & 2 & 6 \\
\hline Total & $\mathbf{5}$ & $\mathbf{5}$ & $\mathbf{2}$ & $\mathbf{7}$ & $\mathbf{1 9}$ \\
\hline
\end{tabular}

Source: Data from field work

\section{Recruitment Strategy and Instrument}

The snowball and convenient sampling strategies were employed to recruit female academics as respondents. First, the snowball approach was to ensure that only female academics with work and family responsibilities were recruited ${ }^{1}$. This was achieved through preliminary referrals from other staff members in identifying those who qualified as case definitions. Second, it was further ascertained that only female academics who are convenient with the nature, structure and timing of the research were finally selected for interview (Shields \& Rangarajan, 2013; Quinlan, 2011). The semi-structure interview type was employed to elicit qualitative data from the recruited female academics. This is justified to give flexibility to the uncovering of supplementary questions and ensure clarity to specific responses in cases of ambiguity (Cooper \& Schindler, 2008). An interview guide was used to ensure consistency in the range of questions asked and responses rendered and all interviews lasted for a period of two months (Odetunde, 2011; Saunders, Lewis \& Thornhill, 2009). There are some known challenges peculiar with the interview method of data collection such as ambiguity in Language- non-clarity of responses to interview questions and the likelihood of misunderstanding between the interviewer and respondents (Collins \& Hussey, 2013). However, these challenges were addressed in this study by ensuring that the

\footnotetext{
${ }^{1}$ Female academics with work and family conflict essentially form the focus of the study. The crux is to understand the dynamics of this conflict in the realm of the COVID-19 pandemic
} 
interview questions were worded in the English-Language method of communication as understood by all respondents and it was also ascertained that the structure of questioning minimizes any likely misinterpretations of the interview questions.

\section{Data Collection Procedure}

The interviews were strictly conducted the through telephone in line with the non-pharmaceutical intervention in the prevention of COVID-19 virus. All the interview sections were pre-recorded and notes taking were employed in some cases to ensure appropriate clarity. The interview process formally begins with a brief introduction of the researcher and the aim of the study. The general question posed to respondents was to uncover the perceptions and views of female academics of work-life conflict in a COVID-19 global pandemic era. The specific questions include what is broad participation of women in the academia? What are the nature of threats between family and work responsibilities? Are women adequately supported to cope with work and family conflicts? What are the existing challenges of the COVID-19 pandemic on work-life conflict? Etc.

\section{Data Quality and Analysis}

The reliability of the qualitative data was explained by adopting Trochim and Donnelly (2007) four indictors of qualitative reliability of data including credibility, transferability, dependability and confirmability. Credibility of the data was ensured by appropriately reflecting the opinion of the respondents in the result, transferability ensured that the results are transferable to another context. Dependability was to ensure that all the procedures comply with ethics of secrecy and accuracy. Lastly, confirmability was to ensure a synchronization between the data and results. The transcripts interviews were all transcribed and the NVivo (v.12) qualitative software employed to make meaning and identify relevant themes and sub-themes that address the research problem. The most frequently mentioned themes were all identified with the use of word cloud. The themes were further re-arranged to ensure that only themes speaking to the research problem forms the analysis. The qualitative content analysis tool was thereafter employed to make sense of the selected themes and sub-themes by provoking major implications from the data. The data engenders a comprehensive overview into the discourse of females views of work-life conflicts in a COVID-19 era. The verbatim responses of all the respondents were employed in the report of the findings. A number of ethical considerations both in the conduct of the study and the report of findings, including that all respondents were properly briefed about the objective of the study and ethical notes were sent to indicate their willingness to participate in the study. In addition, respondents' names and other means of identity were strictly protected in the report of findings in compliance with the ethics of anonymity.

\section{Analysis \\ Women Participation in the Academia}

Women participation in the academia remain diminutive and women continue to fail to advance through the academic echelon in substantial numbers and attain senior level positions. The cultural arrangement and structure of many higher educational institutions are conceived as portraying patriarchal and masculine practices and agenda (Schulz, 2013). The modus operandi associated with the selection process, allocation of research grants has all been abridged to the shortfalls of women participants (Pandu et al., 2013). The efficacy of clarity and accountability employed in the staffing and promotion decisions is ambiguous and gender bias and in interplay with the roles and responsibilities of women academics. The majority of the respondents agreed that women academics roles and job descriptions are frequently designed in context different from other male colleagues. Respondents argued that women academics are generally more reserved for activities outside the confines of research and leaderships such as heading a committee (in the capacity of providing welfare and care) and other non-research and academic leadership positions. A number of women participating in the academia lack concrete role models and the social prejudices attached to their job roles further incapacitate their ability to stretch and advance their networks. Cultural philosophies and customs entrenched in the make-up of a women are signposts to a number of constraining factors preventing the increase participation and development of women in the academia amongst other concerns. The African cultural society conceive of a woman as a home-builder and family custodian whose responsibilities must be exceptionally tied to the home fronts. A senior academic reported as follows:

"Even though the academic was in the time past conceived as a male dominated profession, the crusade for the increase participation of women is still yet to yield any positive outlook. The conventional practice now with women in the academia is that a lot of the times, it is observed that women are not engaged with leadership opportunities in the universities and they are more engaged with some pastoral welfare activities other than the responsibilities of research engagement and other important task".

The academia in Nigeria is characterized with enormous roles and responsibilities for faculty members', especially in the areas of teaching and research. The majority of the respondents expressed a heightened level of concern for women academics who are conceived as non-active participants. For instance, the arguments captured the limited networking opportunities for women academics, the constraints on career growth and advancement due to the existential threats of social and cultural values and norms. The reflection is the fallout in reduced number of women entrants taking up the academic positions and the relegation to low career progression occasioned by ambiguous promotion work practices. Other components address the perception of women academics as second-class participants whose ideal role should be limited to the home. Again, this perception has on many fronts denied many productive and intellectual-driven women into the academia space. A junior female academic recounts in the ensuing paragraphs with notes on personal experience: 
"Our participation here comes with a lot of questions and issues unanswered. Women in this part of the world are designed and excluded from a profession such as the academic by some unguided values systems and practices which have no basis in the discourse of human existence. As an individual, the social construction of female academics has really affected me in the areas of networking for expansion, career development and growth among others and this continues unabated, especially in pluralistic and culture oriented country like Nigeria. This indeed has affected increase women participation".

The majority of the respondents also narrate their perception on the structural barriers in recruitment, selection, promotion and other institutional supports for research and capacity development for women academics. In the areas of recruitment and selection, respondents argued that women are always analysed in terms of unfit owing to existing social barriers and normative value systems. The capacity and capability of women are questioned in line with the societal friction placed on them by culture, religion and other customary practices. According to the large constituents of the respondents, the intentional seclusion of women from the academic has long been a factor with evidence of small number of women seen in the senior academic and leadership positions and this is not going to change earnestly, except there is a room for a systematic adjustment in academic recruitment policies and the inculcation of cultural and social values and belief systems into the academia as the case maybe. One of the junior female academic explained:

"Ours is a system that is so cultural and social eccentric such that important and conventionally practices do not matter to us. From the recruitment and selection down to the promotion and career advancement stage, women have been limited in the academic space. This has been a discouraging factor for many women willing to participate in the academic labour market. We have tended to build standard and competency on the shoulder of cultural and social ideologies thereby discouraging the large pool of female entrants from the academic".

\section{The Existential Threats between Family and Work Responsibilities}

The long work hours characterized with the academia has left many academic women with conflict between work and family responsibilities. For instance, the fragmented and long duration of teachings ${ }^{2}$ in many Nigeria universities is a testament to women academic's failure in balancing the threats between work and family responsibilities. The demand for continuous human capital development such as the possession of $\mathrm{PhD}$ as a requirement for scholarship has further incapacitate women academics ability in ensuring appropriate management of conflict between work and family duties. This perception was shared that the pursuit of higher degree to stay relevant as an academic has denied them adequate responsibilities and commitment to family care and responsibilities with increasing conflicts between the ability to attend to family concerns and work issues. The fallouts of stress from domestic workload, occupational problems and other health issues are fundamental to many women academic's inability to balance the demands and friction between family and work responsibilities. The demand for emotional care from women academics towards their wards and spouse is also signposted as a practical implication constraining women balancing work and non-work activities. One of the respondents reported below with some personal experience hints.

"I have had to contend with a lot of issues between my home fronts and work. I have been a victim of the existential threats between family responsibilities such as ensuring the family is well taking care of in terms of emotional support and otherwise on the one hand, and the need to also ensure that my work as a female academic is sustained and appropriately done as well on the other hand. I have suffered from not knowing what amount of time I need to exert on family and work in order to attain a balance".

The concept of community engagement is gradually becoming robustly entrenched into the job description of academics across the globe (George \& Zhou, 2020; Apodiari \& Lasisi, 2016). The idea is to ensure the transmission of intellectual knowledge unto the development of the immediate community by academics. Women academics are more involved in community engagement activities such as the transfer of skills to their immediate community. The large majority of the respondents agreed that a large component of their work structure constitute commitment to their immediate community. Some of the respondents explain the tussle between the thrive for a balance between work, commitment to community engagement and other family responsibilities. One of the nursing academic mothers explained in the following caption:

"You will agree with me that the introduction of community engagement into the job descriptions of academic is having a more negative outlook on women academics. This is so because a large number of these roles are bequeathed on women academics. Take for instance, I am saddled with a number of community engagement activities because I am a woman and I still have to do my teaching and research activities which are core. I cannot imagine there would not be conflict between these tasks. For me, I am really having a setback in terms of ensuring I have a balance between work and other non-work activities".

Another respondent, a junior lecturer expresses the devastating effect of stress arising from domestic and corporate workload and other occupational health problems on the provocation of work-life conflict. The collection of these problems are consequence for depression, emotional trauma, psychological and psycho-social anxieties among others.

"The challenge is tough. It is so tough especially for someone like me who have young toddlers to give care in addition to ensuring the home front is adequately managed as a woman. I have had to encounter different stress with implications on my health while trying to ensure I have the demands from work and family. I have set into a depressed mood with accompanying psychological

\footnotetext{
${ }^{2}$ Most Nigerian universities normally have contact classes up to $6 \mathrm{pm}$ weekdays with women academics being put in a disadvantage position of balancing family and work simultaneously
} 
problems. It has really been a war trying to ensure these feats are achieved. But one thing I am not sure of is, when will I be able to balance the thrifts between my work and other family duties".

\section{The Challenge of COVID-19 and Work-Life Conflict}

Women in the academia have had to struggle with the demands of a home-maker and work. For instance, the majority of the respondents reported the downside of the work from home concept to include increase responsibilities and demands for emotional care and supports by family members, increase family needs and attention and role conflicts. Majority of the opinions explains that the COVID-19 and work from home narratives have transformed the home into a play and entertainment ground with consequence for work-life conflict. The integration of supervision, consultation, teaching and research and family responsibilities have further engendered a work-life crisis for female academics with parenting responsibilities in this era of global pandemic. The argument, therefore, is founded on the premise that female academics have endured most of the negative outlook of the COVID-19 pandemic. For instance, the focus on child supervision and care explicitly explain the role expectations between men and women. This contention remained a conundrum for women in the academic towards ensuring a balance is realized between work and family responsibilities. One of the respondents explained as follows:

"I think I would like to take the discussion from the perspective of what COVID-19 has made many of our homes look like. You see the idea that we should be working from home is no doubt a great initiative and I want to believe that this is anchored on decreasing the fast spread of the COVID-19 Virus. But coming to specifics, this idea has turned many of homes into a play and entertainment ground. For instance, during the lock-down my home was unconsciously converted into a playing ground with many members of the family at home."

For many of the respondents, the COVID-19 emergence has increased the responsibilities of child supervision, care and the general roles of motherhood in a number of ways, thus leaving a vacuum for role conflict between work and family responsibilities. One of the respondents has the following to say:

"I have to tell you that we are really at the receiving end of this pandemic as female academics, especially those of us with child upbringing and other family responsibilities. In the last two years of COVID-19, I have suffered severe challenges both as a mother and as an academic. I am to ensure my children get the best in terms of qualitative care and also ensure that I meet up with the demands of work. I must confess, COVID-19 has worsened the gap between ensuring my duties as a mother and an academic are balanced"

Another respondent, a senior lecturer reports from the context of career development and meeting up with other assigned university assigned task amidst global health pandemic.

"I have not been able to meet up with the duo of work and family responsibilities since the commencement of the lockdown. I have been challenged with responding promptly to students' emails, consultation and other supervisory tasks. I have also noticed that since the fragmentation of work, I have not been able to develop myself career wise. Take for instance, I have not written or published any academic paper since the beginning of this work restructuring. The challenge is, I have a lot to attend to while working from home and this is conflicting with my work roles".

\section{Discussion}

The COVID-19 pandemic era offers a rich empirical insight for a more robust understanding of work-life conflictual roles. The effective management of work-life conflict has been argued as an important tool for the stimulation of work efficiency and family responsibilities. This importance clearly explains one of the pathways towards building a productive and efficient workforce among others. As shown in this paper, findings show the role of cultural bias in the recruitment and selection process such that many women are positioned to the disadvantaged (Qian \& Fuller, 2020; Ajala, 2017; Akintayo, 2010). More female academics are relegated to committee and teaching responsibilities with sparse participation in research and academic leadership positions. Again, this clearly corroborate the existing cultural and social constraints placed on women in a pluralistic and ethno-cultural infused society like Nigeria where female academics are prejudiced and constrained for capacity development and other academic networking opportunities. These findings support other previous evidence (Agboola, 2019; Boncori, 2020). Findings also show that female academics are always at the downtime of giving quality and appropriate time to either work and family duties. In the orthodox African setting, women are expected to pay more attention to family development and care with little or no attention to conflict arising from work. However, contemporary events seem to have altered this narrative as more women are now giving more time for work than family responsibilities. The challenge of long hours of teaching also represents important constraints for women academics' ability in attaining a balance between work and other family responsibilities. This research finding is reflected in the structure and organization of many Nigerian universities where teachings and learning activities are extended beyond the constitutional allowed work duration. The pursuit of higher education qualification degree on the part of many female academics can also be an extension to explain the unceasing conflictual roles between work and family responsibilities (Qian \& Fuller, 2020; Helvaci et al., 2017). Put together, the results revealed that stress from excessive workload including domestic and occupational workload affect women academic worklife balance in a number of ways (Manzo \& Minello, 2020; Nwagbara, 2020). The study has been able to established that the emergence of COVID-19 has engender major changes in work execution steering up the new concept of work from home. Many 
female academics have had to experience increase emotional demands in terms of care and support from family members. Similar studies conducted in other climes reported similar findings (Qian \& Fuller, 2020; Helvaci et al., 2017). Similarly, the fallouts from the COVID-19 pandemic has transformed the home into a playing ground during the lockdown with growing conflict between work and family for female academics. The shows that female academics work task of supervision, consultation, teaching and research suffered severe setback during the lockdown as integrating these roles with family responsibilities becomes more difficult especially for parenting academics (Aladejebi, 2018). Building a competitive career and research portfolio has remained a constraint for female academics who integrate work and family responsibilities. Previous studies have reported similar outcome (Fatoki \& Kobiowu, 2015; Agha et al., 2017).

\section{Conclusion}

The attention of this study has been to re-imagine how the symbolic theme of work-life conflict provoked the need for a more layered conceptualization of work-life conflict beyond the traditional narrative of the impact on family to a more conventional discourse of the prevailing COVID-19 pandemic. The female academics offer a rich empirical setting for interrogating the themes of women participation in the academic, the existential threats between family and work responsibilities and more importantly the challenges of the COVID-19 pandemic and work-life conflict. Therefore, expanding the empirical discourse of work-life conflict from the prism of female academics and COVID-19 pandemic beyond the traditional conceptualization offers a new research paradigm for appreciating the importance of balancing the conflict between work and family responsibilities. The study concludes that while female academics continue to be affected by the ravaging impact of the COVID-19 global pandemic, the need to encourage female academics to be more psychologically balance cannot be over-stretched. The canon of work-life conflict studies must therefore integrate and reflect more deeply the ideational importance of wellness and well-being as female academics continue with the existing challenge of role conflict between work and family responsibilities. Revisiting this important pathway will allow analysts to stress the analytical discourse of work-life conflict through appropriating for the essential wellness and well-being of female academics as critical for the management of work-life conflicts.

Overall, the study recommends for a more proactive approach on the part of the managers of higher institutions of learning in ensuring workable work-life conflict management strategies are constituted for reduced work-life conflict among female academics. The implication is the rationale for ensure female academics are monitored and evaluated on the efficacy of responses to work and family responsibilities for the avoidance of breakdown, particularly in the epoch of COVID-19 pandemic. The limitation of the methodology can be seen from the focus on three faculties of the University of Lagos. Further study can expand this focus with a more data set through quantitative methods.

Author Contributions: Conceptualization, S.A.; methodology, S.A and P.T.; validation, SA. and P.T.; formal analysis, S.A.; investigation, S.A and P.T.; resources, S.A. and P.T.; writing—original draft preparation, S.A and P.T.; writing—review and editing, S.A. and P.T. All authors have read and agreed to the published the final version of the manuscript.

Institutional Review Board Statement: Ethical review and approval were waived for this study, due to that the research does not deal with vulnerable groups or sensitive issues.

Data Availability Statement: The data presented in this study are available on request from the corresponding author. The data are not publicly available due to privacy.

Conflicts of Interest: The authors declare no conflict of interest.

\section{References}

Adisa, T.A., Adekoya, O.D., \& Okoya, O. (2021). Modern-day slavery? the work-life conflict of domestic workers in Nigeria. Gender in Management: an International Journal, 36(4), 519-535. https://doi.org/10.1108/GM-02-2020-0054.

Agboola, B.G. (2019). Work life balance and role conflict of career women in Ekiti State Civil Service. British Journal of Education, 7(12), 1-6.

Agha, K., Azmi, F.T., \& Irfa, A. 2017. Work-life balance and job satisfaction: an empirical study focusing on higher education teachers in Oman. International Journal of Social Science and Humanity, 7(3), 164-171.

Ajala, E.M. (2017). Work-family-conflict and family-work-conflict as correlates of job performance among working mothers: implications for industrial social workers. African Journal of Social Work, 7(1), 52-62.

Akintayo, D. I. (2010). Work-family role conflict and organizational commitment among industrial workers in Nigeria. Journal of Psychology and Counselling, 2(1), 1-8.

Aladejebi, O.A. (2018). Measuring work-life balance among female owners of community pharmacies in Nigeria. International Journal of Applied Research, 4(6), 307-315.

Apodiari, U., Lasisi, R. (2016). Work-family role conflict and job performance among women bankers in the Federal Capital Territory, Abuja. International Journal of Development and Management Review, 11, 103-119.

Boncori, I. (2020). The never-ending shift: feminist reflection on living and organizing academic lives during the coronavirus pandemic. Gender, Work and Organization, 27, 677-682. https://doi.org/10.1111/gwao.12451.

Collins, J., \& Hussey, R. (2013). Business research: a practical guide for undergraduate and postgraduate students. London: Palgrave Macmillan.

Cooper, D.R., \& Schindler, P.S. (2008). Business research methods. 10th ed. Boston, MA and Burr Ridge, IL: McGraw-Hill. 
Creswell, J.W., \& Plano-Clark, V.L. (2011). Designing and conducting mixed methods research. (2nd ed). Thousand Oaks: Sage Publications.

Dumas, T.L., \& Jeffrey, S. (2015). The professional, the personal, and the ideal worker: pressures and objectives shaping the boundary between life domains. Academy of Management Annals, 9(1), 803-43. https://doi.org/10.1080/19416520.2015.1028810

Erickson, J.J., Giuseppe, M., \& Jeffrey, H. (2010). Putting work and family experiences in context: differences by family life stage.

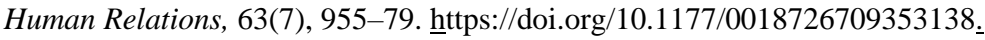

Fatoki, F. T., \& Kobiowu, S. V. (2015). Family and work responsibilities and coping strategies of women academics. European Scientific Journal, 11(34), 309-324.

George, J.M., \& Zhou, J. (2002). Understanding when bad moods foster creativity and good ones do not: The role of context and clarity of feelings. Journal Applied Psychology, 87, 687-697. https://doi.org/10.1037/0021-9010.87.4.687.

Grunberg, L., Matei, S. (2020). Why the paradigm of work-family conflict is no longer sustainable: towards more empowering social imaginaries to understand women's identities. Gender, Work and Organization, 7(2), 289-309. https://doi.org/10.1111/gwao.12343.

Helvaci, M.A., Bakalim, O., \& Can, V. (2017). The work-life balance of academics. Jrn. of New Horizons in Education, 7(4), 80-85.

Katz, D., \& Kahn, R. L. (1978). The social psychology of organizations (2nd edition). New York: Wiley.

Lewis, R.A. (2016). Work-life balance in academia: experiences of lecturers in Switzerland. International Journal of Business and Management, 4(1), 69-84. https://doi.org/ 10.20472/BM.2016.4.1.004

Manzo, L.K.C., \& Minello, A. (2020). Mothers, childcare duties, and remote working under COVID-19 lockdown in Italy: cultivating communities of care. Dialogues in Human Geography, 10(2), 120-123. https://doi.org/10.1177/2043820620934268

Mentz, J.C., Schoeman, M.A., \& Loock, M. (2019). The roles, behaviours and expectations of the participants in the development of student graduations. Innovative Technologies and Learning, 7(4), 435-445.

National Universities Commission-NUC. (2018). Annual report. Abuja: The NUC Publication.

Nwagbara, U. (2020). Institutional and organizational work-life balance policies and practices: exploring the challenges faced by Nigerian female workers. Journal of Work-Applied Man., 12(1), 42-54. https://doi.org/10.1108/JWAM-11-2019-0035

O'Connor, L.T., \& Erin, A. C. (2018). Not just a mother's problem: the consequences of perceived workplace flexibility bias for all workers. Sociological Perspectives, 61(5), 808-29. https://doi.org/10.1177/0731121418768235.

Odetunde, O.J. (2011). Introduction to social scientific research. Ibadan: Lad-Od Prints and Publishing Co.

Onyemah, V. (2008). Role Ambiguity, Role Conflict, and Performance: Empirical Evidence of an Inverted-U Relationship. Journal of Personal Selling \& Sales Management, 28(3), 299-313. https://doi.org/10.2753/PSS0885-3134280306.

Örtqvist, D., \& Wincent, J. (2006). Prominent consequences of role stress: a meta-analytic review. International Journal of Stress Management, 13(4), 399-422. https://doi.org/10.1037/1072-5245.13.4.399.

Pandu, A., Balu. A. \& Poorani, K. (2013). Assessing work-life balance among IT \& ITeS women professionals. Indian Journal of Industrial Relations, 48(4), 611-620.

Phillips, J.A. (2020). Work-life fit during a pandemic. Workplace Health \& Safety, 68(10), 502503. https://doi.org/10.1177/2165079920953830.

Qian, Y., \& Fuller, S. (2020). COVID-19 and the gender employment gap among parents of young children. Canadian Public Policy, 46(2), 89-101. https://doi.org 10.3138/cpp.2020-077.

Quinlan, C. (2011). Business research methods. South-western: Cengage Learning.

Saunders., M. \& Lewis, P., \& Thornhill, A. (2009). Research methods for the business student. England: Pearson Education Limited. Sekaran, U., \& Bougie, R. (2016). Research methods for business: a skill-building approach. 6th ed. United Kingdom: Wiley.

Schulz, J. (2013). The impact of role conflict, role ambiguity and organizational climate on the job satisfaction of academic staff in research-intensive universities in the UK. Higher Education Research \& Development, 32(3), 464-478. https://doi.org/10.1080/07294360.2012.680209.

Shields, P. M., \& Rangarajan, N. (2013). A playbook for research methods: integrating conceptual frameworks and project management. Oklahoma: New Forums Press.

Taggar, S. (2002). Individual creativity and group ability to utilize individual creative resources: a multilevel model. Academy of Management Journal, 45, 315-330. https://doi.org/10.2307/3069349.

Trochim. W. M. K., \& Donnelly, J. (2007). The research methods knowledge base. 3rd ed. Mason, OH: Thomson Custom Publishing. Ugwu, C.J. (2017). Relationship of work-family conflict, family-work conflict and psychological distress among female bank employees in Port Harcourt Metropolis, Rivers State, Nigeria. European Journal of Psychological Research, 4(1), 88-95.

Publisher's Note: SSBFNET stays neutral with regard to jurisdictional claims in published maps and institutional affiliations.

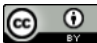

(C) 2021 by the authors. Licensee SSBFNET, Istanbul, Turkey. This article is an open access article distributed under the terms and conditions of the Creative Commons Attribution (CC BY) license (http://creativecommons.org/licenses/by/4.0/).

International Journal of Research in Business and Social Science (2147-4478) by SSBFNET is licensed under a Creative Commons Attribution 4.0 International License. 